\title{
GENOTYPIC ASSESSMENT OF THE LATVIAN RYE (Secale cereale L.) COLLECTION
}

\author{
Agnese Gailite*, Anita Gaile*, Ilze Gaile*, Angelika Voronova*, Ilze Veinberga*, \\ Aina Kokare**, Dainis Edgars Ruṇǵis* \\ * Genetic Resource Centre, Latvian State Forestry Research Institute "Silava", Rīgas iela 111, Salaspils LV-2169, LATVIA \\ ** State Priekuḷi Plant Breeding Institute, Zinātnes iela 2, Priekuḷi LV-4126, LATVIA; \\ dainis.rungis@silava.Iv
}

Communicated by Isaak Rashal

\begin{abstract}
Rye (Secale cereale L.) is an important grain crop in Latvia, where it is mainly used for baking rye bread, which is a popular staple. However, the area under rye cultivation in Latvia is small, and the majority of varieties planted are foreign. In 1937, almost 290000 ha of rye were planted, while in 2011, only 28000 ha were planted, or $~ 5 \%$ of the area planted with cereals. The Latvian rye genetic resources collection contains nine accessions, including old and new cultivars, landraces and one repatriated accession, which was previously held in the N. I. Vavilov Research Institute of Plant Industry collection. A set of descriptors has been developed for rye, and field evaluations of the Latvian rye collection have been started. A set of simple sequence repeat (SSR) markers has been utilised for genetic fingerprinting of the collection. The initial genetic results indicate that the Latvian rye collection contains a high degree of genetic diversity. Analyses are continuing in order to more fully characterise the collection both phenotypically and genetically.
\end{abstract}

Key words: rye, Secale cereale L., SSR markers, phenotypic descriptors.

Rye breeding in Latvia began in 1913, with the establishment of the Priekuli Breeding Station. The material used for breeding included German ('Petkuser') and Estonian ('Sangaste') germplasm. The Latvian Gene Bank holds nine accessions of rye (Secale cereale L.) (Table 1). The majority of the accessions are old varieties or landraces, with 'Kaupo' being the only currently registered Latvian rye variety, which is also the only variety being actively maintained by phenotypic selection. The aim of this study was to utilise SSR markers to investigate the amount of genetic diversity and differentiation within and between the accessions in the Latvian rye genetic resources collection. The collection has also been characterised over three years (2007-2009) according to rye descriptors, which have been developed in Latvia, based on the UPOV descriptors (available at http://www.genres.lv/en/kulturaugi/deskriptori/). The evaluation was carried out at the State Priekuli Plant Breeding Institute. Assessment of disease resistance has not been done in controlled conditions, however field evaluation was possible in 2007 due to conditions favourable for infection, and so data for one year is available. The genotyping and phenotyping results were compared, taking into account the history of the development of the analysed accessions.

The material analysed consisted of seed accessions held in the Latvian Gene Bank (Table 1). The majority of the accessions were received into the gene bank from the State Priekuli Plant Breeding Institute, where they were stored
Table 1

RYE ACCESSIONS STORED IN THE LGB

\begin{tabular}{|c|c|c|}
\hline Accession & Pedigree & \begin{tabular}{|c} 
Year of develop- \\
ment/first release*
\end{tabular} \\
\hline Ārupe & $\begin{array}{l}\text { Recurring family selection from } \\
\text { Nemčinovskaja 50, Vambo and } \\
\text { Dankowske Selekcine } * *\end{array}$ & $1982 *$ \\
\hline Cesvaines & No information, possibly a landrace & \\
\hline Hibrīds II & $\begin{array}{l}\text { Hybrid population (Čulpan (Russia), } \\
\text { Otello (Sweden), EM - } 1 * \text { Vjatka (Rus- } \\
\text { sia), Gibridnaja } 5 \text { (Russia)) } * * * *\end{array}$ & $1982 * * * *$ \\
\hline Jāņu rudzi & No information, possibly a landrace & \\
\hline Stendes II & Stendes $\times$ Petkus $($ short $) \times$ Sangaste $* *$ & $1949 * * *$ \\
\hline Stendskaya II & $\begin{array}{l}\text { Presumed to be an accession of Stendes } \\
\text { II, repatriated from VIR }\end{array}$ & \\
\hline Priekul̦u & Selection from Tērauda $* *$ & $1930 *$ \\
\hline Kaupo & $\begin{array}{l}\text { Family selection from population de- } \\
\text { veloped using Tulvi (Estonia), Glorija } \\
\text { (Germany), Vambo (Estonia), CHD } \\
181 \text { (Germany), Muro (Germany) **** }\end{array}$ & $1998 *$ \\
\hline Vaive & $\begin{array}{l}\text { Selection from tetraploid Petkus }(4 n= \\
28) * *\end{array}$ & $1967 *$ \\
\hline
\end{tabular}

and maintained prior to being placed into the Latvian Gene Bank. The accession 'Stendskaya II' was repatriated from the N. I. Vavilov Research Institute of Plant Industry (VIR), 
and is presumed to be an accession of the variety 'Stendes II'. The only information on this accession in the VIR database indicates that it was placed into the collection in 1952 . Regeneration of accessions in Latvia has been undertaken at the State Priekuli Plant Breeding Institute using isolation in pollination cages.

Seeds of rye accessions stored in the Latvian Gene Bank were germinated and DNA was extracted using a modified CTAB method (Doyle and Doyle, 1987). Five individuals from each accession were genotyped using a total of 12 SSR markers (SCM43, SCM2, SCM86, SCM120, WMS44, WMS6, SCM101, SCM138, SCM75, SCM9, SCM39, SCM5) (Saal and Wricke, 1999). The forward primers were labelled with the fluorescent dyes 6-FAM, HEX or NED in order to facilitate genotyping on an Applied Biosystems $3130 x l$ genetic analyser. PCR amplification conditions were as previously described (Saal and Wricke, 1999). Genotyping was done using GeneMapper 4.0 (Applied Biosystems).

The two accessions which are presumed to be landraces 'Cesvaines' and 'Jāņu rudzi' are characterised by a long stem length, sparse spikelets and low thousand grain weight (TGW). The old cultivars 'Priekulu' and 'Stendes II', which were bred prior to the 1950's, have long stems, medium density spikelets, medium resistance to lodging, and high TGW. The accessions 'Ārupe' and 'Kaupo' are the most modern rye cultivars, which were bred in the 1980's utilising western European germplasm containing recessive short stem length alleles. They have a shorter stem, better resistance to lodging, and shorter and denser spikes. The accession 'Hibrīds II' was developed using germplasm with dominant stem length alleles, and while the average stem length is shorter in this accession, this trait is still segregating quite strongly. 'Hibrīds II' has improved resistance to lodging, and the spikes are longer, with a lower density of spikelets. Disease resistance was only assessed in one year (2007), and only for some of the accessions. However, one of the most resistant accessions was the landrace 'Cesvaines', while the more recently developed cultivar 'Kaupo' was quite susceptible to diseases, especially to leaf rust.

Of the twelve SSR markers utilised, 11 were informative, with the marker SCM86 not yielding genotypes of sufficient quality to be accurately scored. PCR amplification products of the marker SCM138 were scored as two separate loci (Fig. 1). The 11 SSR markers utilised yielded 12 loci which were genotyped in the Latvian rye collection and analysed wirh GenAlEx 6.41 (Peakall and Smouse, 2006) (Table 2). The average number of alleles and observed heterozygosity was similar among cultivars, with the lowest values found in 'Jānu Rudzi'. The fixation index was close to zero in the cultivars. The intra-accession genetic variation was large; analysis of molecular variance (AMOVA) indicated that $92 \%$ of the genetic diversity was found within accessions, and $8 \%$ between accessions $(P<0.005)$. However, each accession contained unique alleles, ranging from 1 found in 'Ārupe' to 6 in 'Stendskaya II' (average 3.4 unique alleles/accession). There was no indication that genetic diversity was higher in the old cultivars and land races, which

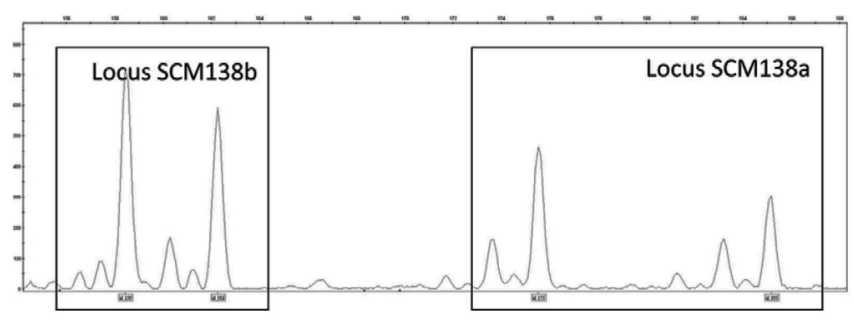

Fig. 1. Example of marker SCM138 genotyped as two separate loci.

could be a reflection of the relatively smaller breeding effort in comparison to other grain crops, leading to a smaller loss of genetic diversity in the modern cultivars. In addition, there is no information on the sampling of the old cultivars and landraces, i.e. the number of individuals genotypes introduced into the genetic resources collection. Inclusion of only a small number of individuals may have resulted in a genetic bottleneck in comparison to the modern cultivars.

Genetic distance between the accessions was calculated using the shared allele method and the robustness of the genetic relationships was examined by bootstrap analysis (1000 bootstraps) using PowerMarker V3.25 (Liu and Muse, 2005). A consensus neighbour-joining dendrogram was constructed using MEGA 5 (Tamura et al., 2011) (Fig. 2 ). The consensus dendrogram indicated that the accession 'Hibrīds II' and 'Stendskaya II' were most distinct from the other accessions, as well as from each other. There was moderate support for the grouping of the remaining accessions into one cluster $(67 \%)$, and also for the similarity of 'Kaupo' and 'Ārupe' (58\%), and 'Priekuḷ' and 'Jāṇu Rudzi' (51\%). The other bootstrap values were below 50\%.

Genotyping data and the phenotyping data were in agreement, and also were comparable to the history of the accessions. The old cultivars 'Priekulu', 'Jāṇu Rudzi' and 'Stendes II' clustered together, and are also similar according to the descriptors, both of them having long stems, and medium spike density and lodging resistance. The accession 'Hibrīds II' is more distinct from the others, and this variety was developed using germplasm with dominant stem length alleles, in contrast to the other shorter accessions 'Árupe' and 'Kaupo'. The repatriated accession 'Stendskaya II' was genetically distant from all the other cultivars, including 'Stendes II'. Unfortunately, no phenotypic information is available for the accession 'Stendskaya II', and thus no comparison with 'Stendes II' could be made. From this data, it is not possible to draw conclusions on the identity of the repatriated accession 'Stendskaya II'. The two supposed

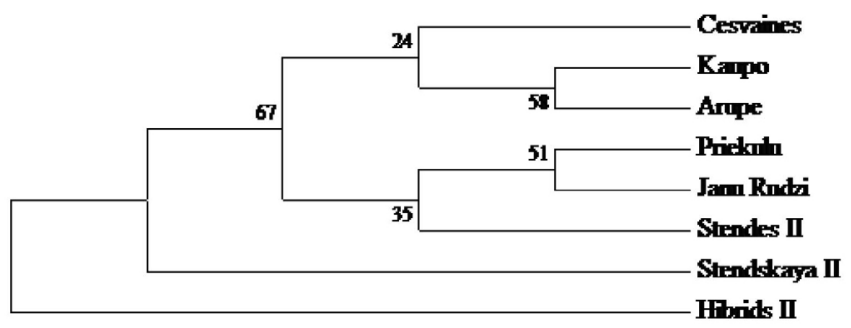

Fig. 2. A bootstrap neighbour-joining dendrogram based on the shared allele genetic distances between the analysed diploid Latvian rye accessions. 
Table 2

GENETIC DIVERSITY PARAMETERS OF THE ANALYSED RYE ACCESSIONS (AVERAGE OVER LOCI UNLESS OTHERWISE STATED).

\begin{tabular}{|c|c|c|c|c|c|c|c|c|c|c|}
\hline Locus & Accession & Jāṇu Rudzi & Cesvaines & Ārupe & Hibrīds II & Kaupo & Priekuḷu & Stendes II & Stendskaya II & $\begin{array}{l}\text { Mean over } \\
\text { accessions }\end{array}$ \\
\hline \multirow[t]{4}{*}{ SCM2 } & $\mathrm{Na}$ & 2 & 3 & 3 & 2 & 3 & 1 & 4 & 2 & 2.50 \\
\hline & Ho & 0.00 & 0.50 & 0.33 & 0.00 & 0.33 & 0.00 & 0.33 & 0.20 & 0.21 \\
\hline & $\mathrm{He}$ & 0.48 & 0.53 & 0.50 & 0.48 & 0.61 & 0.00 & 0.72 & 0.50 & 0.48 \\
\hline & $\mathrm{F}$ & 1.00 & 0.06 & 0.33 & 1.00 & 0.45 & N/A & 0.54 & 0.60 & 0.57 \\
\hline \multirow[t]{4}{*}{ SCM5 } & $\mathrm{Na}$ & 4 & 3 & 5 & 3 & 4 & 2 & 4 & 5 & 3.75 \\
\hline & Ho & 0.40 & 0.50 & 0.67 & 0.20 & 0.67 & 0.50 & 0.33 & 0.60 & 0.48 \\
\hline & $\mathrm{He}$ & 0.48 & 0.63 & 0.78 & 0.46 & 0.72 & 0.38 & 0.72 & 0.68 & 0.61 \\
\hline & $\mathrm{F}$ & 0.17 & 0.20 & 0.14 & 0.57 & 0.08 & -0.33 & 0.54 & 0.12 & 0.18 \\
\hline \multirow[t]{4}{*}{ WMS6 } & $\mathrm{Na}$ & 4 & 2 & 4 & 3 & 4 & 5 & 4 & 4 & 3.75 \\
\hline & Ho & 0.40 & 0.33 & 0.50 & 0.00 & 0.50 & 0.80 & 0.75 & 0.20 & 0.44 \\
\hline & $\mathrm{He}$ & 0.66 & 0.28 & 0.66 & 0.67 & 0.66 & 0.76 & 0.66 & 0.58 & 0.61 \\
\hline & $\mathrm{F}$ & 0.39 & -0.20 & 0.24 & 1.00 & 0.24 & -0.05 & -0.14 & 0.66 & 0.27 \\
\hline \multirow[t]{4}{*}{ SCM9 } & $\mathrm{Na}$ & 3 & 5 & 4 & 3 & 5 & 3 & 3 & 3 & 3.63 \\
\hline & Ho & 0.80 & 1.00 & 1.00 & 1.00 & 1.00 & 0.80 & 0.75 & 0.40 & 0.84 \\
\hline & $\mathrm{He}$ & 0.54 & 0.78 & 0.69 & 0.59 & 0.78 & 0.56 & 0.59 & 0.54 & 0.63 \\
\hline & $\mathrm{F}$ & -0.48 & -0.28 & -0.45 & -0.68 & -0.28 & -0.43 & -0.26 & 0.26 & -0.33 \\
\hline \multirow[t]{4}{*}{ SCM39 } & $\mathrm{Na}$ & 1 & 5 & 2 & 2 & 4 & 4 & 2 & 7 & 3.38 \\
\hline & Ho & 0.00 & 0.67 & 0.00 & 1.00 & 0.50 & 0.25 & 0.33 & 1.00 & 0.47 \\
\hline & $\mathrm{He}$ & 0.00 & 0.78 & 0.44 & 0.50 & 0.72 & 0.66 & 0.28 & 0.84 & 0.53 \\
\hline & $\mathrm{F}$ & N/A & 0.14 & 1.00 & -1.00 & 0.30 & 0.62 & -0.20 & -0.19 & 0.10 \\
\hline \multirow[t]{4}{*}{ SCM43 } & $\mathrm{Na}$ & 3 & 3 & 6 & 5 & 6 & 4 & 3 & 4 & 4.25 \\
\hline & Ho & 0.75 & 0.33 & 1.00 & 1.00 & 1.00 & 0.60 & 0.50 & 0.20 & 0.67 \\
\hline & $\mathrm{He}$ & 0.53 & 0.61 & 0.81 & 0.78 & 0.83 & 0.66 & 0.63 & 0.58 & 0.68 \\
\hline & $\mathrm{F}$ & -0.41 & 0.45 & -0.23 & -0.28 & -0.20 & 0.09 & 0.20 & 0.66 & 0.03 \\
\hline \multirow[t]{4}{*}{ WMS44 } & $\mathrm{Na}$ & 2 & 2 & 2 & 2 & 2 & 2 & 2 & 2 & 2.00 \\
\hline & Ho & 0.20 & 1.00 & 1.00 & 1.00 & 1.00 & 0.50 & 0.67 & 1.00 & 0.80 \\
\hline & $\mathrm{He}$ & 0.18 & 0.50 & 0.50 & 0.50 & 0.50 & 0.38 & 0.44 & 0.50 & 0.44 \\
\hline & $\mathrm{F}$ & -0.11 & -1.00 & -1.00 & -1.00 & -1.00 & -0.33 & -0.50 & -1.00 & -0.74 \\
\hline \multirow[t]{4}{*}{ SCM75 } & $\mathrm{Na}$ & 3 & 3 & 4 & 3 & 2 & 4 & 4 & 4 & 3.38 \\
\hline & Ho & 1.00 & 0.33 & 0.50 & 1.00 & 0.67 & 0.60 & 0.67 & 0.75 & 0.69 \\
\hline & $\mathrm{He}$ & 0.63 & 0.61 & 0.72 & 0.61 & 0.44 & 0.70 & 0.67 & 0.69 & 0.63 \\
\hline & $\mathrm{F}$ & -0.60 & 0.45 & 0.30 & -0.64 & -0.50 & 0.14 & 0.00 & -0.09 & -0.12 \\
\hline \multirow[t]{4}{*}{ SCM101 } & $\mathrm{Na}$ & 3 & 3 & 3 & 3 & 5 & 6 & 4 & 4 & 3.88 \\
\hline & Ho & 0.60 & 0.50 & 0.75 & 0.50 & 0.75 & 0.40 & 0.75 & 1.00 & 0.66 \\
\hline & $\mathrm{He}$ & 0.66 & 0.63 & 0.66 & 0.63 & 0.75 & 0.80 & 0.72 & 0.66 & 0.69 \\
\hline & $\mathrm{F}$ & 0.09 & 0.20 & -0.14 & 0.20 & 0.00 & 0.50 & -0.04 & -0.52 & 0.04 \\
\hline \multirow[t]{4}{*}{ SCM120 } & $\mathrm{Na}$ & 2 & 2 & 3 & 2 & 3 & 3 & 2 & 2 & 2.38 \\
\hline & Ho & 0.33 & 0.33 & 0.50 & 0.40 & 0.50 & 0.60 & 1.00 & 0.20 & 0.48 \\
\hline & $\mathrm{He}$ & 0.28 & 0.28 & 0.41 & 0.32 & 0.41 & 0.46 & 0.50 & 0.42 & 0.38 \\
\hline & $\mathrm{F}$ & -0.20 & -0.20 & -0.23 & -0.25 & -0.23 & -0.30 & -1.00 & 0.52 & -0.24 \\
\hline \multirow[t]{4}{*}{ SCM138a } & $\mathrm{Na}$ & 3 & 4 & 6 & 3 & 5 & 5 & 5 & 5 & 4.50 \\
\hline & Ho & 0.50 & 1.00 & 0.75 & 0.75 & 1.00 & 1.00 & 1.00 & 0.80 & 0.85 \\
\hline & $\mathrm{He}$ & 0.63 & 0.72 & 0.78 & 0.53 & 0.69 & 0.76 & 0.78 & 0.76 & 0.71 \\
\hline & $\mathrm{F}$ & 0.20 & -0.38 & 0.04 & -0.41 & -0.45 & -0.32 & -0.29 & -0.05 & -0.21 \\
\hline \multirow[t]{4}{*}{ SCM138b } & $\mathrm{Na}$ & 4 & 4 & 3 & 2 & 2 & 4 & 2 & 5 & 3.25 \\
\hline & Ho & 0.33 & 0.33 & 0.50 & 0.25 & 0.00 & 0.20 & 0.00 & 1.00 & 0.33 \\
\hline & $\mathrm{He}$ & 0.72 & 0.72 & 0.59 & 0.22 & 0.38 & 0.70 & 0.44 & 0.72 & 0.56 \\
\hline & $\mathrm{F}$ & 0.54 & 0.54 & 0.16 & -0.14 & 1.00 & 0.71 & 1.00 & -0.39 & 0.43 \\
\hline \multirow[t]{4}{*}{ Mean over loci } & $\mathrm{Na}$ & 2.83 & 3.25 & 3.75 & 2.75 & 3.75 & 3.58 & 3.25 & 3.92 & 3.39 \\
\hline & Но & 0.44 & 0.57 & 0.63 & 0.59 & 0.66 & 0.52 & 0.59 & 0.61 & 0.58 \\
\hline & $\mathrm{He}$ & 0.48 & 0.59 & 0.63 & 0.52 & 0.62 & 0.57 & 0.60 & 0.62 & 0.58 \\
\hline & $\mathrm{F}$ & 0.05 & 0.00 & 0.01 & -0.14 & -0.05 & 0.03 & -0.01 & 0.05 & 0.00 \\
\hline
\end{tabular}

Na, number of alleles; Ho, observed heterozygosity; He, expected heterozygosity; F, fixation index 
sister accessions 'Stendskaya II' and 'Stendes II' have been maintained separately for over 60 years. The regeneration history of 'Stendskaya II' is not known, and 'Stendes II' has been regenerated without phenotypic selection. Given the outcrossing nature of rye, and the high levels of genetic diversity within the accessions, it is possible that genetic drift could be responsible for the observed genetic differences. Alternatively, one or both of these accessions could have been cross-pollinated or mislabelled.

The results from this study indicate that while the Latvian rye collection is small, the genetic and phenotypic diversity contained within and between the accessions is quite high. The majority of the collection consists of old varieties and landraces, which contain potentially useful alleles (e.g. disease resistance in the landrace 'Cesvaines'). Given that this material is well adapted to local conditions, this collection will be useful for further rye breeding efforts in Latvia and the surrounding region.

\section{ACKNOWLEDGEMENTS}

Publication of this article was supported by ERDF project No 2DP/2.1.1.2.0/10/APIA/VIAA/021.

\section{REFERENCES}

Bebre, G. (2003). Priekuḷu selekcijas stacija — lauksaimniecības zinātnes centrs Vidzemē [Priekuli Plant Breeding Station — agricultural science centre in Vidzeme]. LLMZA, Agron. Vēstis. 5, 30-36 (in Latvian).

Doyle, J. J., Doyle, J. L. (1987). A rapid DNA isolation procedure for small quantities of fresh leaf tissue. Phytochem. Bull. 19, 11-15.

Lindermanis, J. (1992). Rudzi [Rye]. In: Laukaugu selekcija Latvijā [Crop Breeding in Latvia] (18.-31. lpp.). Holms I. (ed.), Rīga: Avots (in Latvian).

Liu, K., Muse S. V. (2005) PowerMarker: Integrated analysis environment for genetic marker data. Bioinformatics, 21, 2128-2129.

Peakall, R., Smouse, P. E. (2006). GENALEX 6: Genetic analysis in Excel. Population genetic software for teaching and research. Mol. Ecol. Notes 6 , 288-295.

Saal, B., Wricke, G. (1999). Development of simple sequence repeat markers in rye (Secale cereale L.). Genome, 42, 964-972.

Tamura, K., Peterson, D., Peterson, N., Stecher, G., Nei, M., Kumar, S. (2011). MEGA5: Molecular Evolutionary Genetics Analysis using maximum likelihood, Evolutionary distance, and maximum parsimony method. Mol. Biol. Evol., 28, 2731-2739.

Zute, S., Belicka, I., Kalmanis, Z. (2012). State Stende Cereal Breeding Institute: From the origins to present. Proc. Latvian Acad. Sci., Section B, 66 $(1 / 2), 59-70$.

Received 15 April 2013

\section{LATVIJAS RUDZU (Secale cereale L.) KOLEKCIJAS GENOTIPISKAIS NOVĒRTĒJUMS}

Rudzi (Secale cereale L.) ir Latvijā nozīmīga graudaugu suga, un tie galvenokārt tiek izmantoti pārtikā rudzu maizes cepšanai. Rudzu platības Latvijā ir nelielas, un pārsvarā audzēšanai izmanto ārzemju šķirnes. 1937. gadā rudzu sējumi bija gandrīz 290000 ha, savukārt, 2011. gadā — tikai 28000 ha jeb 5\% no visām graudaugu platībām. Latvijas rudzu ǵenētisko resursu kolekcijā ir devinini paraugi — vietējās un selekcionāru izveidotās škiirnes un viens no N. I. Vavilova Viskrievijas augkopības institūta kolekcijas repatriēts paraugs. Rudzu ǵenētisko resursu kolekcija vērtēta lauka apstākḷos atbilstoši izstrādātajiem morfoloğisko pazīmju deskriptoriem. Kolekcijas ğenētiskajā novērtējumā izmantoti SSR (Simple Sequence Repeat) DNS markieri. Sākotnējie genenētiskie rezultāti parāda, ka ğenētiskās daudzveidības līmenis Latvijas rudzu kolekcijā ir augsts. Lai pilnīgāk raksturotu kolekciju (gan fenotipiski, gan genotipiski), pētījumi tiek turpināti. 